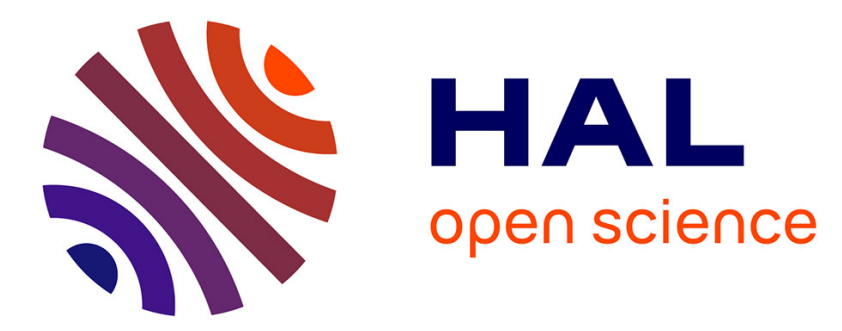

\title{
The origins of foreign exchange policy: the National Bank of Belgium and the quest for monetary independence in the $1850 \mathrm{~s}$ \\ Stefano Ugolini
}

\section{- To cite this version:}

Stefano Ugolini. The origins of foreign exchange policy: the National Bank of Belgium and the quest for monetary independence in the 1850s. European Review of Economic History, 2012, 16 (1), pp.51-73. 10.1093/ereh/her005 . hal-01293694

\section{HAL Id: hal-01293694 \\ https://hal-univ-tlse2.archives-ouvertes.fr/hal-01293694}

Submitted on 25 Mar 2016

HAL is a multi-disciplinary open access archive for the deposit and dissemination of scientific research documents, whether they are published or not. The documents may come from teaching and research institutions in France or abroad, or from public or private research centers.
L'archive ouverte pluridisciplinaire HAL, est destinée au dépôt et à la diffusion de documents scientifiques de niveau recherche, publiés ou non, émanant des établissements d'enseignement et de recherche français ou étrangers, des laboratoires publics ou privés. 


\title{
The Origins of Foreign Exchange Policy: The National Bank of Belgium and the Quest for Monetary Independence in the 1850s
}

\author{
Stefano Ugolini \\ Scuola Normale Superiore di Pisa \\ s.ugolini@sns.it
}

\begin{abstract}
:
The monetary policy trilemma maintains that financial openness, fixed exchange rates, and monetary independence cannot coexist. Yet, in the 1850s, Belgium violated this prediction. Through a study of nineteenth-century monetary policy implementation, this article investigates the reasons for such success. This was mainly built on the stabilisation of central bank liquidity, not of exchange rates as assumed by the target-zone literature. Other ingredients included: the role of circulating bullion as a buffer for central bank reserves, the banking system's structural liquidity deficit towards the central bank, and the central bank's size relative to the money market.
\end{abstract}

JEL: E52, E58, F31, N23.

Keywords: Foreign exchange policy, monetary policy implementation, reserve management. 


\section{Introduction}

In patent violation with the prescriptions of the trilemma, the central bank ${ }^{1}$ of a small open economy was entrusted with an apparently inconsistent mandate: reconciling the defense of fixed exchange rates with monetary independence ${ }^{2}$. Yet the bank spectacularly succeeded in pursuing both targets, thus attracting the interest of international commentators. How was this paradoxical outcome made possible? How did the central bank manage to secure the credibility of the peg despite lack of realignment of the domestic interest rate to international levels? And what special conditions were necessary to the success?

This article provides the first systematic analysis of a pioneering experiment in monetary policy endeavoured by the National Bank of Belgium (NBB, founded 1850) during the first decade of its life. It is organized as follows. Section 2 explains the motivations for this study and describes the issue. Section 3 analyses the NBB's monetary policy and how it was implemented, thus providing a general framework for understanding the micro-foundations of $19^{\text {th }}$-century central banking. Section 4 tests the findings empirically. Section 5 concludes.

The main contribution of the article consists of showing that the creation of credibility through constructive ambiguity was a crucial ingredient of Belgian success. Yet other ingredients played a role: one was the use of circulating bullion as a buffer for central bank reserves; another one was central bank control over the market interest rate; and finally, there was the non-negligible size of the central bank's balance sheet relative to the volume of the money market. All of them testify the existence of sophisticated policy-making in a largely unexplored monetary era.

\section{Motivation}

\section{1: Monetary Independence under Fixed Exchange Rates}

To date, the so-called monetary policy trilemma remains one of the most popular and powerful references of textbook macroeconomic theory. In its simplest form, it consists of the prediction that a country cannot have financial openness, fixed exchange rates, and monetary policy independence at one time. Although empirical research has started to question the assumption that flexible exchange rates are a sufficient condition for monetary independence (Frankel et al. 2004), the trilemma is still generally seen as grounded by long-term historical evidence (Obstfeld et al. 2005).

\footnotetext{
${ }^{1}$ For simplicity, the term 'central bank' is used throughout the article. However, the reader should bear in mind that a $19^{\text {th }}$-century 'central bank' (or more properly said, a privately-owned chartered bank of issue) was something quite different from its nowadays' counterpart - as section 3 makes clear. For a general discussion, see Goodhart (1988).

${ }^{2}$ As in most of the literature, monetary independence is defined here as the divergence of domestic short-term nominal interest rates from international ones. For a discussion of this definition, see Obstfeld et al. (2005).
} 
Fixed exchange rate regimes, however, happen to leave some room for monetary independence. This depends on the fact that in the real world, exchange rates have seldom been fixed at a precise parity; rather, they have generally been left free to fluctuate within a band around a central parity. According to Svensson (1994), this kind of monetary arrangement (called target zone) allows for a certain room of independence in the short term: if the peg is credible, expectations of realignment towards the par prevent the exchange rate from violating the margins of the band when domestic interest rates diverge from foreign ones. Due to its apparent status of a credible and well-behaved target-zone system, the international gold standard has been naturally seen as the ideal candidate for testing to what extent currency bands could deliver the much-wanted degree of monetary independence without impairing the long-term stability of exchange rate parities (Eichengreen and Flandreau 1997). For instance, Bordo and MacDonald (2005) have tested Svensson's (1994) hypothesis on the three core currencies of the classical gold standard era (1880-1914) with positive results. Flandreau and Komlos (2006) have analysed the Austro-Hungarian experience during the two decades preceding the First World War, to conclude that the successful combination of foreign exchange stability and monetary independence rests on both credibility of the central parity and foreign exchange market efficiency.

Yet the question of how credibility can be built - or differently said, of how independence is made possible in practice - still remains to be clarified. Once more, $19^{\text {th }}$-century monetary systems are an ideal ground for investigation. In a recent contribution, Jobst (2009a) argues convincingly that the situation observed by Flandreau and Komlos (2006) heavily depended on the action of the Austro-Hungarian Bank, which was 'micro-managing' foreign exchange markets through sophisticated techniques of intervention. As a result, the role of central banks in creating credibility emerges as a fundamental element of the picture. It must be acknowledged that the case of the Habsburg Empire is a rather special one, as - due to the long-lasting volatility of the national currency - Vienna was host to a liquid forward exchange market. This was not the case in most other financial centres, where forward exchange markets developed in the aftermath of the First World $\mathrm{War}^{3}$. But this does not mean that foreign exchange intervention techniques were unknown elsewhere: recent historical research has shown that the central banks of peripheral countries like Portugal (Reis 2007; Esteves et al. 2009), Norway (Øksendal 2008), or Sweden (Ögren 2007) were important players on the spot exchange market. Nowhere, however, the scale and scope of foreign exchange policy were comparable to those reached by the NBB in its early years.

Although the NBB was not the first central bank to deal with foreign assets ${ }^{4}$, it was undoubtedly the first one to elaborate a consistent body of techniques that can be classified as foreign exchange policy. By the end of the $19^{\text {th }}$ century, the Belgian primacy in this field had become commonplace between economists and practitioners (Conant 1910; Schiltz 2006) 5 .

\footnotetext{
${ }^{3}$ See e.g. Michie (2007) for the case of London.

${ }^{4}$ For instance, Bordo et al. (2007) quote anecdotal evidence of operations in sterling claims by the Second Bank of the United States during the 1820s and 1830s.

${ }^{5}$ See e.g. Palgrave (1903, p. 185): 'Through holding these drafts on other countries the council of the Bank has the means of operating in any direction when the exchanges are unfavourable to Belgium. The moderate rates of discount charged and the comparatively small range of fluctuation show how carefully [...] the Bank of Belgium has maintained this power'. Later on (p. 219) the author seems to suggest that a similar policy should be adopted by the Bank of England (BoE) in order to reduce domestic interest rate volatility: 'No precautions are taken in
} 
The understanding of this pioneering experiment, however, has until now been constrained by lack of information. Except for some scanty statistics contained in its annual reports to shareholders, the NBB did not disclose any kind of datum concerning its operations. This explains why early commentators, such as Conant (1910), Van Elewyck (1913), or Witten (1918), were unable to enter into much detail on the question. As a result, the Belgian experience failed to translate into 'best practice' for potential imitators despite its international renown. The fact that even in archives nothing concerning the management of foreign reserves had apparently survived, moreover, discouraged a focused analysis by the official historians of the NBB, Kauch (1950) and Buyst et al. (2005). This article fills this gap by building on newly-collected databases constructed from previously unused files.

Figure 1 about here

\section{2: The Belgian Puzzle of the 1850s}

Figure 1 shows something strange: since the opening of the NBB's counters in January 1851, the Belgian franc turned from a high-yield to a low-yield currency. How was this possible? Some tentative explanations may come to mind.

First, one might think that decoupling was the effect of the monetary arrangements in force at the time. In the mid- $19^{\text {th }}$ century, different regimes coexisted (gold standard, silver standard, bimetallic); despite the remarkable stability of the gold-silver ratio throughout the period (Flandreau 2004), expectations of future changes in this ratio might have created 'peso problems' in bilateral foreign exchange relationships. Ugolini (2010) investigates the phenomenon for five top international currencies during the period 1844-1870, and concludes that such problems existed up to a certain extent. The scale of risk premia, however, was smaller and more volatile than the one exhibited in the Belgian case. Moreover (and more importantly), places on the same metallic foot as Antwerp (like Amsterdam, Hamburg, and Frankfurt) displayed completely different patterns. Therefore, bullion prices do not provide an answer to the puzzle. It was the Belgian franc itself to enjoy a negative 'peso problem' with respect to all other currencies, which means that the phenomenon was fully country-specific.

Second, the astonishing stability of the Antwerp market interest rate after the foundation of the NBB might look suspicious. The domestic market rate almost constantly coincided with the Bank's discount rate, which acted as its upper bound (see table 1). It might be tempting to infer that the 'true' market rate was higher than the bank rate because of some form of credit rationing. Yet no quantitative or qualitative evidence of rationing does exist. As it was common practice among coeval central banks, the NBB stood ready to freely discount eligible

this country as at the Banks of Germany, Belgium, and elsewhere to mitigate the pressure of an unfavourable exchange by holding bills on other countries which can be "melted" when the need arises'. Not all comments were favourable, though. For instance, Juglar (1889, p. 173) argued that the Belgian experience 'did not deliver the results that such an ingenious strategy seemed to promise, hence it has not been implemented elsewhere, and lack of imitators is enough to prove its uselessness'. The argument sounds rather surprising, especially in the light of the widespread international adoption of foreign exchange policies in the very same years Juglar was writing. 
paper from agreed discounters: while the entry barrier to agreed counterparts may have played a role in reducing speculation ex-ante, it was something completely different from ex-post rationing ${ }^{6}$. As shown by extensive empirical evidence in section 4 , lack of capital mobility can be definitely ruled out.

Therefore, no ready explanation is available for the situation illustrated by figure 1 . This article provides the micro-foundations of that macroeconomic puzzle, originated in the peculiar institutional arrangements that presided over the creation of Belgium's central bank.

Table 1 about here

\section{3: Institutional Background}

The NBB was founded in the aftermath of the 1848 convertibility crisis with a clear mandate for preserving the Belgian franc's peg to silver: central bank money had to be fully convertible into silver species on demand, and a fractional bullion reserve had to be maintained (Statutes, article 13). However, the NBB also had another important (albeit informal) mandate for keeping the domestic interest rate low (Kauch 1950, pp. 58-59 and 99). This was intended to benefit both the economy and the Treasury itself, which had been issuing debt in national currency since 1844 (Depouhon 1873). Evidence of governmental pressure aimed at discouraging rate increases often emerges in the $\operatorname{archives}^{7}$, but the mandate looked like a 'gentlemen's agreement' between the Board and the Treasury rather than a formal rule. As the Statutes did not mention the objective explicitly, the Bank was left free to set the policy it thought to be the most appropriate. In this context, foreign exchange policy quickly emerged as the most convenient solution for reconciling the two targets.

The NBB had not been designed to perform foreign exchange policy: the Statutes of 1850 never mention foreign reserves - neither to allow nor to forbid them. This vagueness was crucial in shaping the NBB's action, based on a mix of transparency and opacity. The Bank was required to disclose its balance sheet monthly, but it was not compelled to provide details on foreign reserves (which were merged with domestic assets). While outsiders could be sure that the Bank respected legal requirements (viz. maintaining the minimum bullion coverage ratio), they knew nothing on the way this was made possible. Aimed at positively influence market expectations, this constructive ambiguity was key to the establishment of a credible peg. Section 3 explains how.

\footnotetext{
${ }^{6}$ Kauch (1950, pp. 94-97 and 122-128) provides details on eligibility criteria applied by the NBB in the 1850s. Far from being restrictive, they look similar (if not laxer) to those implemented in France or Britain. These are discussed at length by Bignon et al. (2011) and Flandreau and Ugolini (2011).

${ }^{7}$ Within the minutes of the Administration Board (PV CdA) see for instance: $8^{\text {th }}$ and $11^{\text {th }}$ October $1853 ; 24^{\text {th }}$ December $1853 ; 9^{\text {th }}$ and $21^{\text {st }}$ January $1854 ; 29^{\text {th }}$ November $1855 ; 29^{\text {th }}$ October $1857 ; 5^{\text {th }}$ and $14^{\text {th }}$ November $1857 ; 6^{\text {th }}$ and $20^{\text {th }}$ February $1858 ; 12^{\text {th }}$ January $1860 ; 17^{\text {th }}$ April 1860 ; etc.
} 


\section{The NBB in Context: Monetary Policy Implementation in the $19^{\text {th }}$ Century}

\section{1: The Central Bank's Balance Sheet}

In order to understand how the NBB built the credibility of the peg, it is convenient to provide an overview of what monetary policy was and how it was implemented in the $19^{\text {th }}$ century. This implies, as a first step, a thorough analysis of the micro-foundations of central banking viz. the structure of the central bank's balance sheet, the instruments at its disposal, and the targets of monetary policy ${ }^{8}$. Albeit focused on the Belgian case, the overview offers a number of comparative insights that may be of value for a general reassessment of monetary policy implementation in the $19^{\text {th }}$ century.

Table 2 provides a list of the components of the NBB's balance sheet, as well as some statistics about their relative size during the first three years of life of the Bank. On the asset side of the published balance sheet, one finds (besides a few minor items) four major components: 1) the bullion reserve, made up of silver and gold species and bars ${ }^{9}$; 2) Belgian Treasury securities; 3) advances on national sovereign bonds ${ }^{10}$; and 4) the portfolio of commercial bills, including foreign reserves (viz. bills payable abroad). As the composition of this portfolio was undisclosed, data shown in Table 2 had to be computed from archival sources (see paragraph 4.1).

On the liability side of the balance sheet, one finds three major items: i) capital and reserves; ii) banknotes in circulation; and iii) deposits. While the bulk of liabilities consists of banknotes, the size of deposits is considerable. Given the fact that deposits were not remunerated, this is a rather surprising feature for a country that lacked both a centralized clearing house for interbank payments and (either formal or informal) reserve requirements ${ }^{11}$. Although the NBB never provided details on the composition of this item, some coeval observers argued that more than $85 \%$ of it consisted of Treasury deposits (Brasseur 1864). Unfortunately, no official data are available to confirm or dismiss such allegations - which nonetheless seem to be plausible (Van Elewyck 1913). If this were actually the case, Government balances may be seen as a sort of permanent (and unremunerated) investment in the (privately-owned) central bank. The role of this informal 'subsidy' in providing the NBB with additional resources was far from negligible.

Table 2 about here

\footnotetext{
${ }^{8}$ The literature on the micro-foundations of monetary policy implementation has developed recently. This section draws inspiration mainly from Bindseil (2004), Disyatat (2008), and Jobst (2009b).

${ }^{9}$ While required of keeping central bank money fully convertible into silver species, the NBB was left free to determine the composition of bullion reserves.

${ }^{10}$ Unlike most other central banks of the time, the NBB was forbidden both to purchase on its own account and to accept as collateral for advances any kind of stocks and bonds, except those issued by the Treasury. This norm was formally intended to avoid the risk of excessive immobilization (Kauch 1950), but the idea that the Bank had to focus on enhancing the liquidity of government securities certainly played a role (Depouhon 1873).

${ }^{11}$ For instance, the fact that in the second half of the $19^{\text {th }}$ century deposits at the BoE grew more and more sizeable was due both to the institution of an interbank clearing house settling in BoE balances (1854) and to the establishment of informal reserve requirements after the Baring crisis (Sayers 1936).
} 
As it was typically the case for $19^{\text {th }}$-century central banks (and in stark contrast with nowadays' practice), most of the NBB's activities passed through the Bank's standing facilities - or differently said, they mostly consisted of operations accomplished on demand of the public. The Bank stood ready to provide unlimited access to these facilities at its counters located throughout the country. Two types of operations were supplied without restriction: a) repurchase agreements on Belgian sovereign bonds, and b) discounts (i.e. open-window purchases) of short-term Belgian-franc-denominated bills ${ }^{12}$. Besides these regular facilities, other extraordinary ones could be offered to the public in special circumstances: discounts of short-term foreign bills and foreign exchange repurchase agreements. Being optional operations which could be discontinued by the Bank at any time, they will be treated separately (see paragraphs 3.5 and 3.6 respectively).

Like today, in the $19^{\text {th }}$ century the interest rate at which the central bank stood ready to provide liquidity through its discount facility worked as an upper bound for domestic interbank rates. Yet unlike today, there was no other rate the central bank considered as desirable but the one charged at its standing facility ${ }^{13}$. As a result, the differential between market and bank rate reveals the ability of the central bank to influence the short-term rate. By construction, such an ability closely depends on the structural liquidity deficit of the banking system with respect to the central bank - i.e. the need for domestic agents to resort to central bank credit in order to accomplish their ordinary operations (Bindseil 2004). Hence, the differential between market and bank rate can be seen as a raw indicator of the degree of dependence of the domestic financial sector from central bank lending: the smaller the differential, the larger the structural liquidity deficit ${ }^{14}$. As seen, table 1 points to a strong ability by the NBB to influence the domestic rate ${ }^{15}$.

Besides providing liquidity to the public on demand, the NBB was also implementing open market operations (OMOs) - or differently said, transactions accomplished on initiative of the institution itself. They consisted of outright purchases or sales of those securities the Bank was allowed to be invested in. According to widespread $19^{\text {th }}$-century practice, the central bank was not used to buying or reselling domestic bills in the open market ${ }^{16}$. As a result, the only instruments the NBB could use for its OMOs were a) Belgian sovereign bonds and b) foreign bills. The scale and scope of these operations are discussed in paragraph 3.4.

\footnotetext{
${ }^{12}$ The Bank discounted freely three-name bills payable in Belgium with a maturity not exceeding 90 days. Twoname bills were also discounted, albeit at a higher rate.

${ }^{13}$ The desired level of the domestic interbank rate was functional to the defence of convertibility (see paragraph 3.3). The first central bank to distinguish between the rate offered for unlimited credit at the standing facility and the desired interbank rate was the BoE, which in 1877 began to discount at a lower rate than the official one (Sayers 1936). A similar approach had been adopted in 1825-1844 (Wood 1939).

${ }^{14}$ Properly speaking, the structural liquidity deficit should be measured as the difference between liquidityinjecting and liquidity-absorbing monetary policy operations by the central bank. Yet it is impossible to apply this definition correctly to the case of $19^{\text {th }}$-century central banks because of the difficulty of separating monetary policy operations from autonomous factors (esp. in the case of banknote circulation).

${ }^{15}$ This was not the case, for instance, in Britain, where the money market 'outside the Bank' was large and the BoE's ability to influence the interbank rate was limited. The inconvenience of this situation prompted Threadneedle Street to find devices in order to 'make the Bank rate effective' (Sayers 1936).

${ }^{16}$ This seems to have been a general rule everywhere, including Britain (Sayers 1936).
} 


\section{3: The Targets of Monetary Policy}

Central banks have both final and operational targets. Nowadays, most central banks have price stability as their final target, and some other variable (typically, a short-term interest rate) as their operational one ${ }^{17}$. Markets are generally aware of the importance of operational targets and look at them in order to assess the central banks' ability to achieve their long-term objectives. In the $19^{\text {th }}$ century, most central banks had the defence of convertibility as their main final target. Contrary to the assumptions of the target-zone literature, the operational target through which this was pursued did not consist of the maintenance of exchange rates within the bullion points (i.e. avoiding bullion drains from the country), but of the preservation of a 'margin of manoeuvre' available for performing countercyclical action without breaking convertibility rules ${ }^{18}$. Such a margin can be called excess reserves, or central bank liquidity $(L)$.

What was the level of central bank liquidity to target? As a matter of fact, a trade-off existed: as well as too low a level endangered convertibility, too high a level impaired the central bank's profitability. Both risks put a question mark on the long-term sustainability of current monetary arrangements, and thus on the credibility of the peg. As a result, central banks had to find the right equilibrium level for this operational target.

Central bank liquidity was defined differently across countries. Two systems prevailed:

1) In the differential system ${ }^{19}$, the central bank was allowed to issue freely a fixed amount of banknotes, while any extra banknote put into circulation had to be met by a $100 \%$ bullion backing. In this case, the operational target $L_{D i f}$ consisted of what Bagehot (1873) called the cash reserve - i.e., the amount of banknotes that could still be put into circulation without breaking statutory rules:

$$
L_{\text {Dif }}=B^{c}+M-B^{i}
$$

where $B^{c}$ is the fixed amount of banknotes the bank is allowed to issue without bullion backing, $M$ is the bullion reserve, and $B^{i}$ is the amount of banknotes already issued ${ }^{20}$.

\footnotetext{
17 'An operational target is an economic variable that the central bank wants to control and indeed can control to a very large extent on a daily basis through the use of its monetary policy instruments. [...] The final target of monetary policy is the economic variable that the central bank eventually aims at. Thus, operational [...] targets are nothing more than means towards reaching the final target without a specific value of their own.' (Bindseil 2004, pp. 7-9).

18 'Countercyclical action' means here the central bank's provision of liquidity to the domestic banking system during a crisis, when a scramble for cash takes place in the interbank market. In contrast with today, in the $19^{\text {th }}$ century central banks' ability to meet the banking system's demand for high-powered money was limited by convertibility rules; as a result, the size of the above-mentioned 'margin of manoeuvre' signalled to the public how remote the possibility of a disruption of liquidity provision was. Anecdotal evidence suggests this margin played a pivotal role in driving expectations: during the crises of 1847, 1857, and 1866, for instance, panic in the London money market receded on the announcement that Peel's Act would be temporarily suspended - which meant that the BoE's margin of manoeuvre would temporarily become unlimited (Bagehot 1873).

${ }^{19}$ This system was adopted in Britain in 1844. Other countries (e.g. Norway) had similar arrangements.

${ }^{20}$ This interpretation of the BoE's reaction function builds on the accounts of contemporary observers. A drop in the cash reserve amounted to what Dornbusch and Frenkel (1984) call 'an internal drain'. As central bank liquidity was a synthetic indicator of the overall position of the Bank, this interpretation is not necessarily inconsistent with the results of Jeanne (1995) or Davutyan and Parke (1995).
} 
2) In the proportional system ${ }^{21}$, the central bank was only allowed to issue banknotes against a given fraction $\gamma$ of bullion kept in reserve. Typically (as in the Belgian case), compulsory bullion backing applied not only to the banknote circulation, but also to all other sight liabilities. In this system, the operational target $L_{\text {Prop }}$ consisted of the cash surplus - i.e., the amount of bullion that was not backing the monetary base:

$$
L_{\text {Prop }}=M-\gamma\left(B^{i}+D\right)
$$

where $D$ is the amount of deposits with the bank.

In both the differential and proportional systems, central bank liquidity had a full informational value as an indicator of the monetary authority's funds available for acting counter-cyclically. This item was closely watched by the public in order to understand how much the bank could react to shocks without impairing convertibility - or differently said, how credible the peg was. As a result, stabilising the level of central bank liquidity was supposed to enhance the credibility of the peg in the long term, thus producing stabilising expectations (and mean-reverting speculation) in the foreign exchange market.

\section{4: Choice of the Instrument}

The stabilisation of central bank liquidity was pursued by $19^{\text {th }}$-century monetary authorities through different strategies, according to the different institutional framework in which they operated. For instance, taking advantage of the sensitivity of international gold flows to the London interbank rate, the BoE heavily relied on interest rate policy in order to push bullion back and forth from its vaults (Sayers 1936). Yet such a strategy implied an extreme interest rate volatility that came to be criticized by coeval observers (Palgrave 1903). Moreover, the action of peripheral central banks could not possibly have the same impact as the Bank of England's on international bullion markets. As a result, the techniques that could be adopted in places like Belgium needed to be very different from those implemented in core countries. As pointed out in paragraph 3.2, the instruments at the NBB's disposal included both standing facilities and OMOs. In order to achieve its operational target, the Bank had then two options: either changing the conditions for access to discounts and advances, or intervening directly on its own initiative. Despite being completely free to move the bank rate, there were at least two reasons that deterred it from doing this too frequently: the informal mandate to maintain a low domestic rate discouraged any increase, while profitability concerns discouraged any decrease. Hence, the Bank was generally inclined to act as much as possible through OMOs, which could concern (as seen) two different kinds of securities: Belgian sovereign bonds and foreign bills. In the 1850s, however, national Treasury bonds were still fairly illiquid securities, and the Bank abstained from producing volatility into this market ${ }^{22}$. Moreover, looking at the published balance sheet, the public was able to appreciate variations in the amount of Government bonds held - and thus to assess the extent of the Bank's action. By

\footnotetext{
${ }^{21}$ This system was adopted by most Continental countries, including France and Belgium.

${ }^{22}$ The amount of sovereign bonds held by the NBB remained fairly stable over time. For instance, in the period from February 1851 to December 1853 only two major changes took place: an increase from BEF7m to BEF14m in February 1852 (when the Bank underwrote a new 5\% loan), and a decrease to BEF9m in August 1853 (RAG, 1851-1853).
} 
contrast, as the NBB was not required to disclose the composition of its commercial portfolio, operations in foreign bills could be easily hidden to the general public - as no outsider ever knew the size of the Bank's foreign reserves. Both the liquidity of foreign exchange markets and the degree of secrecy allowed for transactions in these assets made them emerge as the ideal tool for achieving the operational target.

\section{5: Achieving the Operational Target in Ordinary Conditions}

Foreign reserves seemed a particularly apt instrument for monetary policy implementation for an additional reason as well: the NBB was able to adapt with a considerable degree of precision their size to the level needed in order to counterbalance variations in central bank liquidity. This was not the case for any of the other components of the asset side of its balance sheet. As said, the Bank was expected to be invested in a certain sum of national Treasury securities, whose dismissal (or accumulation) by the institution would have engendered turbulence in an illiquid market. Being the recipient of the Bank's standing facilities, the amount of both advances and discounted domestic bills was demand-driven. The same was the case for the bullion reserve, whose repartition between 'compulsory' reserve and cash surplus depended on the size of sight liabilities - deposits and banknotes in circulation, in turn two demand-driven items.

Diagrams 1.1-2 help highlight how playing with foreign reserves proved a convenient policy instrument for the stabilisation of central bank liquidity. The illustration is based on a simplified version of the balance sheet, including: on the asset side, the bullion reserve $(M)$, the domestic portfolio $\left(P^{d}\right)$, and the foreign portfolio $\left(P^{f}\right)$; on the liability side, banknotes in circulation $\left(B^{i}\right)$ and deposits $(D)$. The bullion reserve can be split into two different items, viz. the cash surplus $L$ and the 'compulsory' reserve $M^{c}$, defined as

$$
M^{c}=\gamma\left(B^{i}+D\right)
$$

where $\gamma=1 / 3$.

OMOs on foreign bills aimed at stabilising the cash surplus (or differently said, conversions of $P^{f}$ into $L$ and vice-versa) could be sterilised or not. On the one hand, a sterilised operation consisted of a direct conversion of bullion into foreign bills (and vice-versa), leaving the liability side of the Bank's balance sheet unchanged - and thus, having no impact on domestic agents (see diagram 1.1). On the other hand, a non-sterilised operation consisted of exchanging foreign bills against high-powered money (and vice-versa) ${ }^{23}$, implying changes on both sides of the Bank's balance sheet - and thus, entailing modifications in the liquidity of the domestic banking system (see diagram 1.2) ${ }^{24}$. A trade-off existed between these two techniques for controlling $L$ by acting on $P^{f}$. Sterilised operations were more expensive than

\footnotetext{
${ }^{23}$ For simplicity, diagram 1.2 assumes that non-sterilised operations only impacted banknote circulation. This is reasonable in view of the finding that deposits mostly consisted of Government's and not of bankers' balances.

${ }^{24}$ The NBB often combined OMOs with the introduction of new standing facilities: when purchasing foreign bills on its own initiative, the Bank started discounting the same assets on demand (Ugolini 2011). This being an optional facility, the Bank could discontinue it at any time: as a result, it was not fundamentally dissimilar to non-sterilised OMOs.
} 
non-sterilised ones: while buying or selling foreign bills against banknotes virtually entailed no transaction costs, purchasing or dismissing bullion abroad always implied a number of non-negligible fees ${ }^{25}$. However, as diagram 1.2 shows, non-sterilised operations were a rather inefficient technique for converting $P^{f}$ into $L$ (and vice-versa): only one-third of the total change in the foreign portfolio (and in circulation) translated into a change in the cash surplus, and beyond a given level, their impact on the monetary base could be big enough to entail destabilising effects on the domestic money market. As a consequence, fine-tuning of central bank liquidity required the Bank to implement non-sterilised operations close to the targeted level of $L$ (where the required adjustment was small) and sterilised operations far from that level (where the required adjustment was big).

Thanks to daily OMOs on foreign bills, the NBB was able to achieve the operational target without having to modify access conditions to its standing facilities. This allowed for the stabilisation of bank rates in ordinary times. In case of shocks, however, such a strategy might not have been enough to counteract a reduction in $L$, and the Bank could be forced to resort to other instruments in order to resume a convenient level of central bank liquidity.

\section{Diagrams 1.1 and 1.2 about here}

\section{6: Achieving the Operational Target in Extraordinary Conditions}

Inasmuch as the stabilisation of central bank liquidity could enhance the credibility of the peg, there always existed a given level of interest rate differentials at which exchange rates would move beyond the bullion points anyway. In such an event, the structure of the domestic bullion market played a role in determining the behaviour of monetary authorities. If the country had a large stock of circulating bullion to meet the demand for export, the outflow would not necessarily translate into a run on central bank reserves. Conversely, intervention would be needed if the drain directly impacted the central bank. In the latter case, reactions differed according to specific institutional frameworks. While the BoE used to react by aggressively increasing the discount rate, the NBB was prompted by its informal mandate to try some alternative strategies in the first place.

On $20^{\text {th }}$ October 1855, the Governor told the Administration Board:

'If [1] the domestic portfolio were to grow and [2] the foreign portfolio were to halve with respect to its current level, then there would be room for [3] raising the interest rate on repurchase agreements before changing [4] the discount rate and [5] eligibility criteria for domestic bills'.

This is perhaps the best synthetic enunciation of the NBB's strategy in the event of monetary disturbances. First of all, the Bank would continue to lend freely to domestic agents in order to meet increasing demand. Secondly, it would start selling foreign assets in order to counter the decrease of the cash surplus without reducing loans to the domestic system. Thirdly, it would raise the interest rate on foreign exchange repos in order to shrink profitability margins for bullion exporters. Fourthly, in case all the previous steps had not been enough, it would

\footnotetext{
${ }^{25}$ These are the same fees allowing for the existence of bullion points (freight, insurance, loss of interest).
} 
resort to raising the discount rate. If and only if this latter measure had not worked (which never happened to be the case, except at the outbreak of war in July 1870), then the Bank would change eligibility criteria for domestic bills - which amounted to de facto credit rationing.

The alternative strategies put in place by the NBB consisted of steps 2 and 3. Step 2 had a two-edged aspect. From the point of view of the Bank, OMOs on foreign bills could be useful not only to refurbish reserves. If performed on a focused bilateral foreign exchange market and on a sufficiently large scale, they could also have an impact on exchange rates - or differently said, they could become foreign exchange (plain vanilla) interventions. The rationale was straightforward: by selling foreign bills on the domestic market, the NBB could try to pull the exchange rate within the bullion points, thus annihilating the net profitability of arbitrage. This strategy could prove successful in the very short term. As the Bank refused to borrow reserves abroad, however, it found a natural limit in the depletion of the portfolio of that specific currency ${ }^{26}$.

Step 3 concerned a different level of intervention. In August 1851 the Bank had opened a new standing facility, named achats et ventes d'effets sur l'étranger: the Bank bought spot foreign bills and resold them forward at the same price plus a fixed interest rate. This is the first documented case of a central bank using this kind of instruments. The facility was supposed to be an ideal tool for exporters: as the interest rate applied by the NBB was homogeneous on all kinds of foreign bills, the repo rate often happened to be lower than the interest rate applicable on that currency - which made the choice of borrowing on the security of bills more convenient than discounting them on the market. As a consequence, repos began to be widely used by a particular class of exporters, i.e. bullion arbitrageurs. The Bank typically raised the repo rate before all other rates in order to counter silver shipments ${ }^{27}$. The move was supposed to have the same effect as plain vanilla interventions, i.e. shrinking profitability margins for bullion exporters. As this facility was fully optional to the Bank, it could be discontinued in case of need: this had the potential to impact exchange rates in the short term by forcing potential borrowers to liquidate their foreign claims on the market.

Steps 2 and 3 were aimed at delaying, not at replacing the eventual increase of the domestic discount rate ${ }^{28}$. Nonetheless, this lag allowed the NBB to resist during the initial phases of an international disturbance, and to start raising its discount rate much later than all other central banks. At the peak of the crisis, there still were margins for the full effect of a restrictive policy to be felt by domestic agents. The effectiveness of interest rate policy was tied to the net liquidity deficit of the domestic banking system with respect to the central bank, and such a deficit was apparently quite large (see paragraph 3.2). As a result, external pressure tended to recede before the effects of delayed restrictive policy faded - i.e. before the NBB was obliged to realign the domestic rate to international levels. Skilfully playing this waiting game, the Bank became able to provide the country with that degree of monetary independence contemporaries came to admire.

\footnotetext{
${ }^{26}$ Borrowing reserves was a technique other central banks did not refuse to adopt, but came at a remarkable cost - as shown by the experience of the Bank of Portugal (Reis 2007).

${ }^{27} \mathrm{PV} \mathrm{CdA}, 7^{\text {th }}$ and $23^{\text {th }}$ December $1854 ; 20^{\text {th }}$ October $1855 ; 17^{\text {th }}$ and $29^{\text {th }}$ January $1856 ; 17^{\text {th }}$ June $1856 ; 2^{\text {nd }}$ April 1859. As time passed and the turnover of repurchase operations grew, the NBB tried to restrict access to this facility to Belgian agents only, refusing to accept bills directly remitted by foreign bankers.

${ }^{28} \mathrm{PV} \mathrm{CdA}, 19^{\text {th }}$ October 1854.
} 


\section{The NBB at Work: Empirical Evidence}

\section{1: Data}

In spite of the absence of the ledgers covering foreign exchange operations, it is nonetheless possible to reconstruct the NBB's action by using other archival material. The minutes of the Administration Board report every purchase and sell order the Bank decided to execute. Although the source is often elusive about amounts, the duration of operations is always given. As a result, one can construct a quantitative series of foreign exchange operations based on the total purchasing and selling times ${ }^{29}$.

Albeit limited to the sub-period 1851-1853, the actual amounts of foreign exchange operations are provided by the Governor's correspondence. As the overwhelming majority of domestic operations on foreign bills were implemented in Antwerp and not in Brussels, it is possible to track transactions one-by-one on the letters exchanged with the Bank's branch. This allows for the creation of a high-frequency database ${ }^{30}$.

In the remainder of this section, data on actual amounts transacted (1851-1853) are employed to study those aspects of the NBB's policy whose analysis requires precise, high-frequency data (OMOs and foreign portfolio management), while data on the length of operations (18511861) are used to document the Bank's reaction to the shocks taking place during the decade.

Figures 2.1, 2.2, 2.3, and 2.4 about here

\section{2: The Operational Target: Exchange Rates vs. Central Bank Liquidity}

Paragraph 3.3 argued that the operational target through which the NBB pursued the final target of maintaining convertibility was not the stabilisation of exchange rates within the bullion points, but the stabilisation of its own cash surplus. The proposition is tested here by looking into detail at the Bank's operations during the period 1851-1853 ${ }^{31}$.

For the four main currencies the Bank was dealing in ${ }^{32}$, figures 2.1-4 show the distribution of weekly foreign exchange operations ${ }^{33}$ vis-à-vis the deviation of the exchange rate $^{34}$ from the

\footnotetext{
29. The duration of intervention has been taken as a proxy for size even by some contemporary scholars (Dominguez and Frankel 1993, p. 73). When data on length and amount of operations are both available in our sample (as for 1851-1853), the fit is always good.

${ }^{30}$ Based on the Governor's correspondence (IC 1851-1853), the database has been cross-checked to match the data occasionally provided by other sources (PV CdA 1851-1853; RAG 1851-1853).

${ }^{31}$ This period can be qualified as a time span in which 'ordinary conditions' prevailed, with the exception of November-December 1853 when the Crimean War erupted.

${ }^{32}$ In the period 1851-1853, the NBB implemented open market operations in six different currencies (French franc, British pound, Dutch guilder, Hamburg mark banco, Frankfurt guilder, Prussian thaler). Operations in bills on Frankfurt and Berlin, however, only had a limited scale because of the illiquidity of the bilateral exchange markets (bills on Belgium were not even quoted in the two German centres).

${ }^{33}$ Purchases of foreign bills have a positive sign, while sales of foreign bills have a negative sign.

${ }^{34}$ The exchange rate is defined here as the price of a unit of foreign currency expressed in terms of the domestic unit.
} 
arbitrated par at the beginning of the week. The arbitrated par represents the central value to which the Belgian franc is pegged and with respect to which the bullion points (i.e. the limits of the 'no-arbitrage zone') are computed ${ }^{35}$. If foreign exchange operations were aimed at stabilizing exchange rates (leaning-against-the-wind interventions), one would expect them to have a strict NW-SE configuration (purchases of foreign currency when its price is low, sales when it is high). Yet this is not the case: considerable transactions were implemented when the exchange rate was closed to the par or even beyond it (leaning-with-the-wind interventions). Impacting exchange rates may have been one of the determinants of open market operations, but it clearly was not the first one.

This is confirmed by the Bank's portfolio management strategy. In case foreign reserves had been cumulated with the aim of defending the value of the Belgian franc, one would expect the NBB to hold a considerable 'armoury' especially denominated in core currencies. Yet figure 3 shows that the amount of reserves in the most important international currency of the time (the British pound) varied considerably in the years under scrutiny, up to the point of disappearing completely for a long sub-period (June to December 1852). While dismissing sterling, the NBB diversified its foreign portfolio considerably by starting to buy minor currencies it had never held before. This suggests that other reasons than creating an 'arsenal' for intervention guided the Bank's portfolio management ${ }^{36}$. The obvious candidate is profitability. Returns on foreign bills depended on two components: a) the current yield of the given asset (i.e. the market interest rate) and b) future variations of the exchange rate. While the first component was certain for the Bank, the second one was not. However, a credible fixed-exchange-rate regime implies that expectations concerning the future path of exchange rates must be mean-reverting; although the time horizon for the realignment to take place is uncertain, the direction of the movement must be certain. For the main 'reshufflings' of the foreign portfolio implemented by the Bank, table 3 provides data on both the average 'opportunity cost' of holding the asset until its quarterly maturity (column A) and the average degree of overvaluation of the currency in which the asset was denominated (column B: see table for details). Although investment choices were mainly dictated by expected exchange rate realignments, interest rates also played a role (as e.g. in the case of the Prussian thaler). On the whole, expected returns emerge as the driver of the Bank's foreign portfolio allocation.

Therefore, exchange rates were the main determinant of the composition of $P^{f}$, but not of its size. As a matter of fact, portfolio diversification could be enacted without necessarily impacting the Bank's balance sheet ${ }^{37}$. OMOs determining the volume of reserves had a different driver: the level of central bank liquidity. Figure 4 shows the distribution of monthly

\footnotetext{
${ }^{35}$ The computation of arbitrated pars is discussed by Ugolini (2010). As prices of ingots were not quoted in Belgium, the price of silver was replaced by the metallic content of legal-tender full-bodied species. This is reasonable, as bullion arbitrage from Belgium always took the form of shipments of silver 5 -franc species.

${ }^{36}$ This is not completely the case for the second core currency of the time, the French franc, whose holdings by the Bank never fell beneath a certain level. As shown by figures 2.1-4, the French franc was basically the only one on which the NBB enacted sterilised OMOs; this was due to the de facto currency union between France and Belgium (Parker Willis 1901), which allowed the Bank to buy silver 5-franc species in Paris and immediately use them to pay for its own banknotes in Brussels. As a result, the minimum level of French francs can be considered as the only foreign reserve strictu sensu held by the NBB.

${ }^{37}$ Reshufflings in the composition of the foreign portfolio could be implemented abroad by directly swapping one foreign currency against the other.
} 
foreign exchange operations vis-à-vis the level of $L$ at the beginning of the month. In spite of some noise (tied to the length of the time unit) ${ }^{38}$, it is possible to observe that foreign reserves decreased when $L$ was small and increased when $L$ was large. Also the choice of the type of transaction depended on $L$ : non-sterilised operations (whose impact on the monetary base was huge) were mostly performed when the required adjustment of $L$ was small, while sterilised operations (whose impact on the monetary base was limited) were mostly performed when the required adjustment of $L$ was large. Finally, the chart suggests that the level of central bank liquidity targeted by the Bank during these years was around BEF7.5m - something like 7\% of the average size of the balance sheet and $18 \%$ of the average size of bullion reserves.

Table 3 and figures 3 and 4 about here

\section{3: The Operational Target: Reaction to Shocks}

Paragraph 3.6 argued that OMOs were implemented with the aim of impacting exchange rates (or differently said, that they became foreign exchange interventions properly speaking) in extraordinary conditions only - viz., in the event of a bullion drain affecting central bank reserves. The proposition is tested here by looking at the NBB's action on the franc/sterling bilateral exchange market in 1851-1861, when the Bank performed at least six interventions explicitly aimed at lowering the price of claims on London ${ }^{39}$.

Figure 5 juxtaposes the gross profitability of exporting silver species from Belgium to Britain with quantitative and qualitative evidence of silver shipments ${ }^{40}$ : it suggests that exports of bullion took place when the gross profitability of the transaction exceeded around $0.5 \%$, where the bullion export point must have been located. The striking thing is that the exchange rate on London was often above this threshold during the decade - almost constantly from June 1855 to December 1857, and again from October 1858 to June 1860 . Yet, as shown by figure 6 , intervention on sterling was not implemented by the NBB throughout these periods of exceptional weakness of the franc. As a matter of fact, the six special operations were only performed when the Bank's cash surplus was collapsing - i.e. when the silver exported by arbitrageurs directly came from the NBB's vaults. When silver in circulation provided enough supply to exporters, instead, the central bank did not feel compelled to intervene and let the exchange rate fluctuate freely beyond the bullion point.

Figures 5 and 6 about here

\footnotetext{
${ }^{38}$ While data on OMOs are available on a daily basis, data on balance sheet components are only available on a monthly basis. Unfortunately, this does not allow to catch the effects of abrupt variations in $L$ during the month. ${ }^{39}$ The term 'explicitly' here means that the minutes of the Administration Board (which were undisclosed to the public) clearly report the Directors' intention to impact exchange rates; it does not mean that such an objective was publicly announced.

${ }^{40}$ Quantitative evidence consists of amounts of silver species shipped by the Brussels agent of NM Rothschild \& Sons to the London house. Qualitative evidence consists of written witnesses of silver shipments to Britain by Belgian arbitrageurs: these are taken from two different sources (the Rothschild correspondence and PV CdA).
} 
Paragraph 3.6 argued that foreign exchange intervention was part of a strategy aimed at delaying increases of the discount rate. This is illustrated here by an analysis of the Bank's reaction to the most violent shock of the decade - the 1857 crisis.

Figure 7 shows that in the early spring of 1857, improving central bank liquidity suggested the NBB to drop its rate in spite of the weakness of the Belgian franc with respect to the British pound. Unfortunately, this coincided with tighter money on the London market: silver shipments to Britain intensified, and the Bank's bullion reserve shrank due to withdrawals by exporters. This prompted the Bank to implement direct intervention on the foreign exchange market. Since mid-April, conspicuous sales of sterling were enacted in Antwerp. These plain vanilla interventions only had limited (and short-lived) effects in pushing the exchange rate down to the arbitrated par - they met some success in July, which quickly abated as soon as the Bank's sales stopped. Moreover, the fall of sterling was also tied to a temporary ease in the London market rate, which decreased more than $1 \%$ in the same weeks. Nonetheless, sales proved effective in stopping the fall of $L$.

In mid-July, however, bullion reserves sunk dramatically; by the end of the month, they fell slightly below the statutory coverage ratio of one-third of the Bank's sight liabilities ${ }^{41}$. In view of the depletion of the sterling portfolio, the NBB rapidly raised its repo rate to the maximum level allowed by the Code de Commerce (an usury ceiling was still fixed at $6 \%$ ) ${ }^{42}$. This brought the NBB repo rate to a higher level than the London market rate, thus annihilating the convenience of using this facility for exporting silver to Britain.

A period of ease followed. In late August and September the profitability margins of shipping silver shrank, and the Bank's cash surplus was restored. In the early days of October, however, Britain was hit by panic, and the London interbank rate skyrocketed. As soon as it went above $6 \%$, the NBB decided to suspend repurchase facilities altogether. At this point only, in front of a sharp drop in bullion reserves, the discount rate on domestic bills was raised twice. Yet at the very peak of the crisis, when the London rate touched $10 \%$, this $2 \%$ increase to $5.5 \%$ was enough for reversing the trend: by the end of November, $L$ was growing steadily. In the space of a few weeks the crisis was over, without the Bank having to raise its discount rate to the foreign levels.

The NBB's reaction to the 1857 crisis shows how monetary independence was pursued in practice: thanks to a skilful combination of devices, the Bank was able to delay a realignment of the domestic interest rate to the international level. While ineffective in the long term, such a policy worked very smoothly in the short term. As liquidity crises tended to be rather short-

\footnotetext{
${ }^{41}$ The Statutes of the NBB gave the Finance Minister the power of allowing the minimum coverage ratio to pass temporarily from one-third to one-fourth of sight liabilities. The Minister preferred the Bank to let the cash surplus turn negative rather than to raise the discount rate abruptly, and gave his consent. This was also the case at the peak of the crisis: PV CdA, $14^{\text {th }}$ November 1857.

${ }^{42}$ During the 1857 crisis, usury ceilings were abolished in many European countries (including France). At the peak of the storm, the NBB consulted the Government on the prospect of taking the same step in Belgium as well; the Finance Minister showed a positive attitude and prepared a bill to be proposed to the Parliament, but the worst was over before the move became necessary. The usury ceiling was definitively repealed a few years later (Kauch 1950, pp. 121-122).
} 
lived, however, the technique proved well-suited to the needs of a $19^{\text {th }}$-century small open economy.

Figure 7 about here

\section{Summary and Conclusions}

This article has provided the first detailed analysis of a pioneering $19^{\text {th }}$-century monetary experiment which allowed for the maintenance of financial openness, a fixed exchange regime, and a remarkable degree of monetary independence at the same time. The success of this experiment depended on a number of special ingredients. They may be summarized as follows.

First and foremost, as predicted by the literature on target zones, the establishment of the credibility of the peg was the basic ingredient of the recipe. But contrary to the assumptions of this literature, credibility was not built through the stabilisation of exchange rates, but through the stabilisation of central bank liquidity (i.e. the funds available for countercyclical action before letting the peg go). The strategy rested on a skilful combination of transparency (the Bank published data on its own liquidity) and opacity (nothing was known about the way stabilisation was obtained through the use of foreign exchange reserves). This constructive ambiguity proved effective in enhancing the credibility of the Belgian currency.

The second ingredient of the NBB's success was the reliance on the stock of circulating bullion as a buffer for central bank reserves. Thanks to the existence of this stock, not all outflows of bullion called for central bank intervention. This provided monetary authorities with room for flexibility ${ }^{43}$.

The third ingredient was the effectiveness of interest rate policy. As the effects of foreign exchange intervention are generally short-lived, intervention merely consisted of a technique for delaying a modification in access conditions to the central bank's standing facilities. Once interest rate policy was implemented, however, its impact was fully felt by the domestic money market thanks to the structural liquidity deficit of the banking system.

Last but not least, despite the need to meet this deficit, the central bank had ample excess resources to be invested in foreign assets: this was made possible by the size of the Bank's liabilities, to which Treasury deposits contributed substantially. The Government had asked the Bank to keep domestic interest rates low with the aim of reducing the cost of sovereign borrowing, but in order to make this possible it had to contribute to the expansion of the NBB's balance sheets. As deposits were not remunerated, the move must have entailed a nonnegligible loss of interest ${ }^{44}$.

\footnotetext{
${ }^{43}$ This opens an interesting perspective: future research might want to investigate if one of the conditions that impaired the working of the interwar gold standard with respect to the pre-war one was the disappearance of this buffer.

${ }^{44}$ Available data do not allow to dress a benefits/costs balance for this choice. However, the long-term benefits of transforming the Belgian franc into a low-yield currency must have been substantial for government borrowing as well. As early as 1874 , Belgium was already perceived as the country with the lowest yields on sovereign bonds besides Britain (The Economist, $3^{\text {rd }}$ January 1874, p. 6).
} 
All in all, the Belgian experience of the 1850s opens scope for a general reassessment of the working of $19^{\text {th }}$-century international monetary systems. Far from being rudimentary and automatic, they were actively micro-managed through extremely sophisticated sets of monetary policies by shrewd central bankers. No doubts, they still hide many useful lessons for the present that only a micro-oriented historical research will be able to reveal.

\section{Acknowledgements}

For their useful comments on previous versions of this work, many thanks are also due to Olivier Accominotti, Vincent Bignon, Marcello De Cecco, Rui Pedro Esteves, Marc Flandreau, Clemens Jobst, Robert McCauley, Anders Ögren, Lars Fredrik Øksendal, Jaime Reis, Herman Van der Wee, as well as the editors, two anonymous referees, and participants to presentations in Paris, Edinburgh, Bergen, Utrecht, and Lisbon. Kind assistance in archival research by Geert Leloup, Arnold De Schepper and Melanie Aspey, as well as financial support by Scuola Normale Superiore and Norges Bank, are gratefully acknowledged. The usual disclaimers apply.

\section{Archival Sources}

Archives Générales du Royaume/Algemeen Rijksarchief (Brussels), Fonds Banque Nationale:

- PV CdA: Procès-verbaux du Conseil d'Administration (Minutes of the Board of Directors), 1850-1861 (9 volumes).

- IC: Indicateur de la correspondance du Gouverneur (Index of the Governor's correspondance), 1851-1853 (6 volumes).

Banque Nationale de Belgique/Nationale Bank van België (Brussels), Archives Centrales/Centraal Archief:

- RAG: Rapports du Gouverneur à l'Assemblée Générale des actionnaires (Annual Reports to Shareholders), 1851-1861 (1 volume).

The Rothschild Archive (London), Correspondence Department:

- XI/38/212A-B: Lazare Richtenberger (Brussels), 1851-1853.

- XI/78/0A-2B: Samuel Lambert (Brussels), 1853-1861. 


\section{Published Sources}

- Cours authentique de la bourse de Bruxelles (1851-1861).

- Journal de Commerce d'Anvers (1844-1861).

- The Economist (1851-1861; 1874).

\section{References}

- Bagehot, Walther (1873), Lombard Street: A Description of the Money Market, London: King.

- Bignon, Vincent, Marc Flandreau, and Stefano Ugolini (2011), Bagehot for Beginners: The Making of Lending of Last Resort Operations in the Mid-19 $9^{\text {th }}$ Century, Economic History Review, forthcoming.

- Bindseil, Ulrich (2004), Monetary Policy Implementation: Theory, Past, Present, Oxford: Oxford University Press.

- Bordo, Micheal D., and Ronald MacDonald (2005), "Interest Rate Interactions in the Classical Gold Standard 1880-1914: Was There Any Monetary Independence?", Journal of Monetary Economics, 52, pp. 307-327.

- Bordo, Michael D., Owen Humpage, and Anna J. Schwartz (2007), "The Historical Origins of US Exchange Market Intervention Policy", International Journal of Finance and Economics, 12, pp. 109-132.

- Brasseur, Henri (1864), La Banque nationale et la liberté des banques, Antwerp: De la Montagne.

- Buyst, Erik, Ivo Maes, Walter Pluym, and Marianne Danneel (2005), The Bank, the Franc, and the Euro: A History of the National Bank of Belgium, Tielt: Lannoo.

- Conant, Charles A. (1910), The National Bank of Belgium, Washington DC: National Monetary Commission.

- Davutyan, Nurhan, and William R. Parke (1995), "The Operations of the Bank of England 1890-1908: A Dynamic Probit Approach", Journal of Money, Credit and Banking, 27:4, pp. 1099-1112.

- Depouhon, François (1873), Euvres complètes de François De Pouhon, précédées d'une notice sur la vie de l'auteur et ses écrits, Brussels: Gobbaerts.

- Disyatat, Piti (2008), "Monetary Policy Implementation: Misconceptions and Their Consequences", BIS Working Papers No. 269.

- Dominguez, Kathryn M., and Jeffrey A. Frankel (1993), Does Foreign Exchange Intervention Work?, Washington DC: Institute for International Economics.

- Dornbusch, Rudiger, and Jacob A. Frenkel (1984), "The Gold Standard Crisis of 1847”, Journal of International Economics, 16, pp. 1-27. 
- Eichengreen, Barry J. and Marc Flandreau (1997), "Editors' Introduction", in id. (eds.), The Gold Standard in Theory and History, $2^{\text {nd }}$ ed., London: Routledge, pp. 121.

- Esteves, Rui P., Jaime Reis, and Fabiano Ferramosca (2009), "Market Integration in the Golden Periphery: The Lisbon/London Exchange 1854-1891", Explorations in Economic History, 46, pp. 324-345.

- Flandreau, Marc (2004), The Glitter of Gold: France, Bimetallism and the Emergence of the International Gold Standard 1848-1873, Oxford: Oxford University Press.

- Flandreau, Marc, and John Komlos (2006), "Target Zones in Theory and History: Credibility, Efficiency, and Policy Autonomy”, Journal of Monetary Economics, 53:8, pp. 1979-1995.

- Flandreau, Marc, and Stefano Ugolini (2011), "Where It All Began: Lending of Last Resort and the Bank of England during the Overend-Gurney Panic of 1866", in Michael D. Bordo and William Roberds (eds.), A Return to Jekyll Island: The Origins, History, and Future of the Federal Reserve, Cambridge: Cambridge University Press, forthcoming.

- Frankel, Jeffrey A., Sergio L. Schmuckler, and Luis Servén (2004), "Global Transmission of Interest Rates: Monetary Independence and Currency Regime", Journal of International Money and Finance, 23, pp. 701-733.

- Goodhart, Charles A. E. (1988), The Evolution of Central Banks, Cambridge (Mass.): MIT Press.

- Jeanne, Olivier (1995), "Monetary Policy in England 1893-1914: A Structural VAR Analysis", Explorations in Economic History, 32, pp. 302-326.

- Jobst, Clemens (2009a), "Market Leader: The Austro-Hungarian Bank and the Making of Foreign Exchange Intervention 1896-1913", European Review of Economic History, 13, pp. 287-318.

- Jobst, Clemens (2009b), "Monetary Policy Implementation during the Crisis in 2007 to 2008", Monetary Policy and the Economy, 9:1, pp. 53-77.

- Juglar, Clément (1889), Des crises commerciales et de leur retour périodique en France, en Angleterre et aux États-Unis, Paris: Guillaumin.

- Kauch, Pierre (1950), La Banque Nationale de Belgique 1850-1918, Brussels: BNB.

- Michie, Ranald C. (2007), "The City of London as a Global Financial Centre 18801939: Finance, Foreign Exchange, and the First World War”, in Philip L. Cottrell, Evan Lange, and Ulf Olsson (eds.), Centres and Peripheries in Banking: The Historical Development of Financial Markets, Aldershot: Ashgate, pp. 41-80.

- Obstfeld, Maurice, Jay C. Shambaugh, and Alan M. Taylor (2005), "The Trilemma in History: Tradeoffs among Exchange Rates, Monetary Policies, and Capital Mobility”, Review of Economics and Statistics, 87:3, pp. 423-438.

- Ögren, Anders (2007), "Lender of Last Resort in a Peripheral Economy with a Fixed Exchange Rate: Financial Crises and Monetary Policy in Sweden under the Silver and Gold Standards 1834-1913”, in Philip L. Cottrell, Evan Lange, and Ulf Olsson (eds.), Centres and Peripheries in Banking: The Historical Development of Financial Markets, Aldershot: Ashgate, pp. 223-252. 
- Øksendal, Lars F. (2008), "Monetary Policy under the Gold Standard: Examining the Case of Norway 1893-1914", mimeo.

- Palgrave, R. H. Inglis (1903), The Bank Rate and the Money Market in England, France, Germany, Holland, and Belgium 1844-1900, London: Murray.

- Parker Willis, Henry (1901), A History of the Latin Monetary Union: A Study of International Monetary Action, Chicago: University of Chicago Press.

- Reis, Jaime (2007), “An 'Art', Not a 'Science'? Central Bank Management in Portugal under the Gold Standard 1863-1887”, Economic History Review, 60:4, pp. 712-741.

- Sayers, Richard S. (1936), Bank of England Operations 1890-1914, London: King.

- Schiltz, Michael (2006), “An 'Ideal Bank of Issue': The Banque Nationale de Belgique as a Model for the Bank of Japan”, Financial History Review, 13:2, pp. 179196.

- Svensson, Lars E. O. (1994), "Why Exchange Rate Bands? Monetary Independence in Spite of Fixed Exchange Rates”, Journal of Monetary Economics, 33, pp. 157-199.

- Ugolini, Stefano (2010), "The International Monetary System 1844-1870: Arbitrage, Efficiency, Liquidity”, Norges Bank Working Paper 2010/23.

- Ugolini, Stefano (2011), "An 'Atypical' Case? The First Emergence of Brussels as an International Financial Centre 1830-1860”, in Youssef Cassis and Laure QuennouëlleCorre (eds.), Institutions, Markets and Capital Flows from the 1880s to the Present: Why Are Financial Centres Attractive?, Oxford: Oxford University Press, forthcoming.

- Van Elewyck, Ernest (1913), La Banque Nationale de Belgique: Les théories et les faits, Brussels: Falk.

- Witten, Paul (1918), "Die Devisenpolitik der Nationalbank von Belgien”, Schmöllers Jahrbuch für Gesetzgebung, Verwaltung und Volkswirtschaft im Deutschen Reich, 42:2, pp. 193-228, and 42:3, pp. 135-170.

- Wood, Elmer (1939), English Theories of Central Banking Control 1819-1858, Cambridge (Mass.): Harvard University Press. 


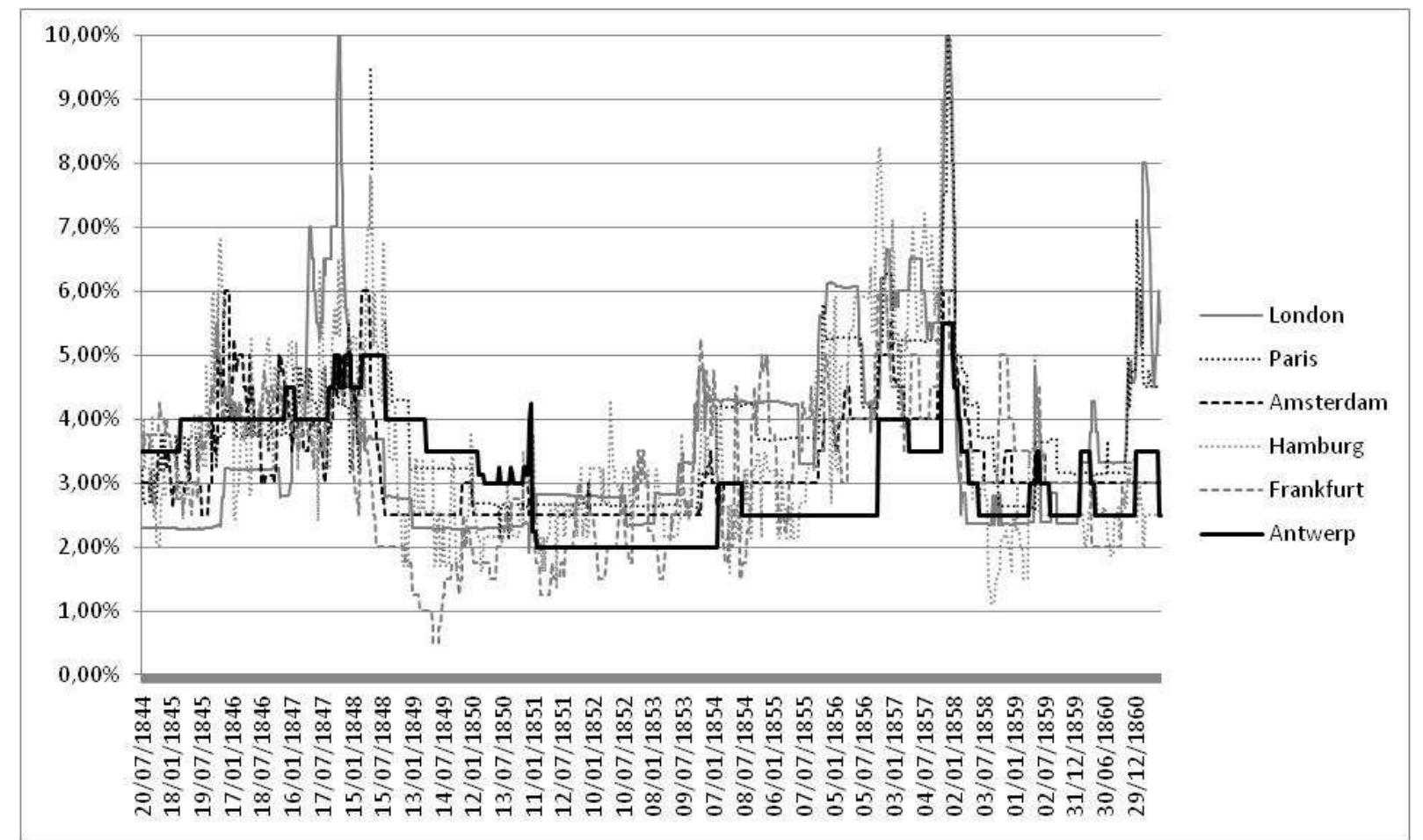

Figure 1: Market interest rates in six financial centres (weekly), 1844-1861. Source: Ugolini (2010), except Antwerp (Journal de Commerce d'Anvers). 
Figures 2.1-4: Weekly foreign exchange operations (in million Belgian francs) vis-à-vis the deviation from the arbitrated parity, 1851-1853. White triangles: non-sterilised operations; grey squares: sterilised operations. Sources: NBB interventions: author (IC, PV CdA, RAG, 1851-1853); exchange rates: Cours authentique de la bourse de Bruxelles; bullion prices: Ugolini (2010).

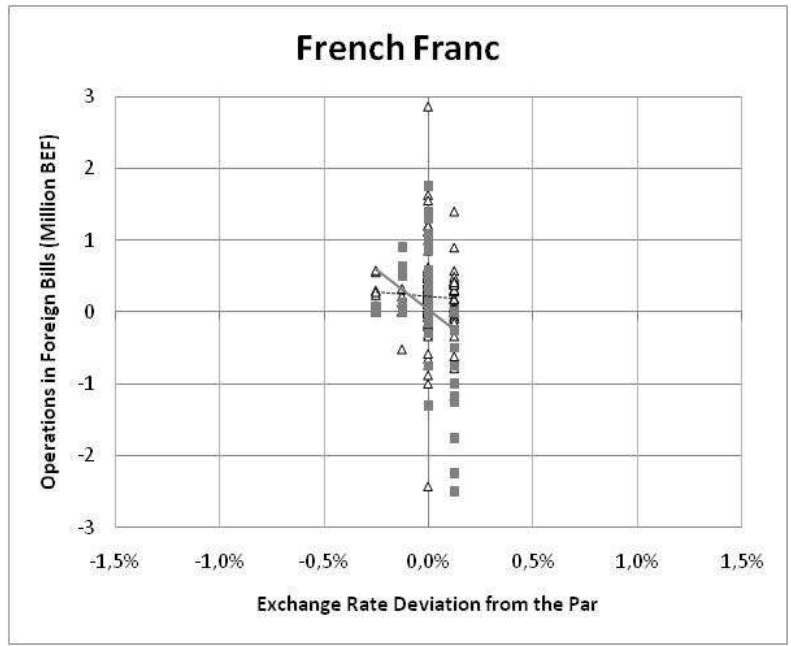

Figure 2.1: Operations on French francs.

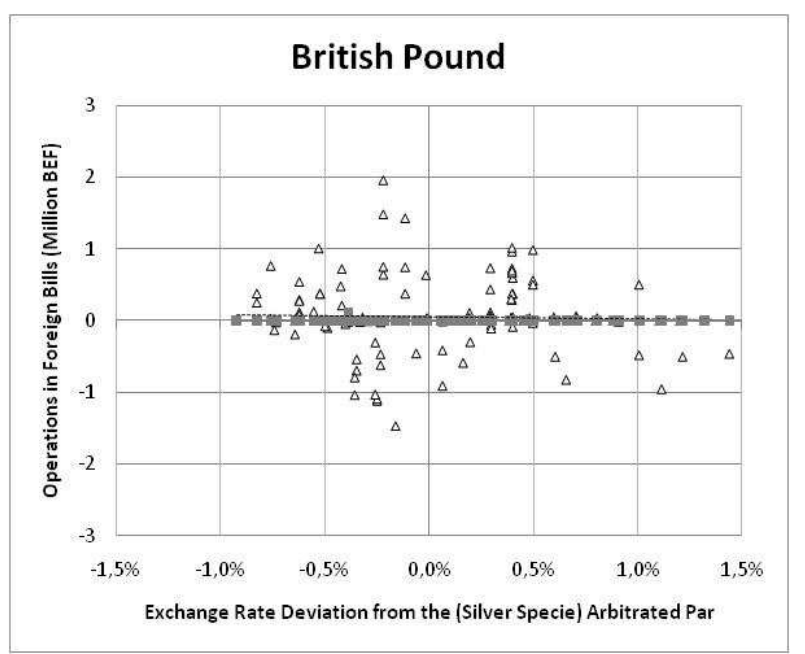

Figure 2.2: Operations on British pounds. 


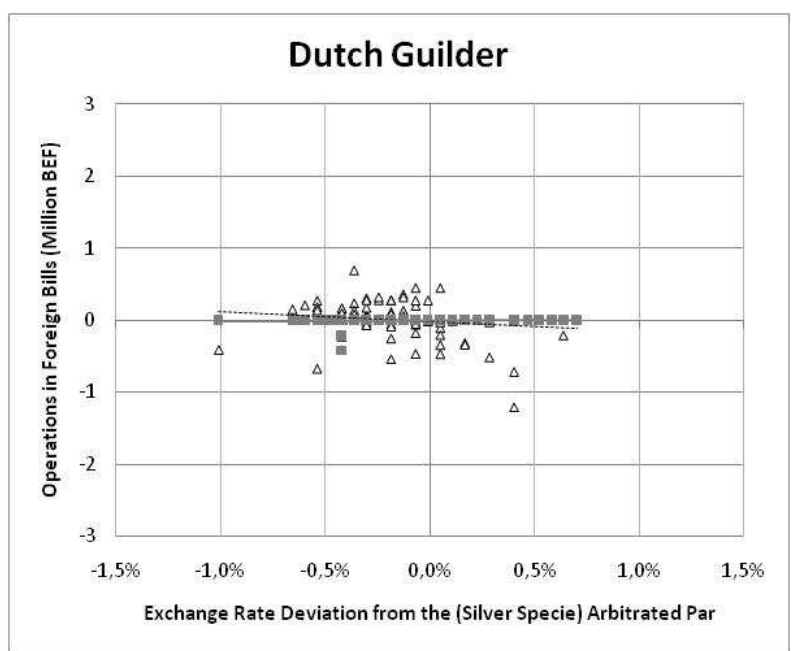

Figure 2.3: Operations on Dutch guilders.

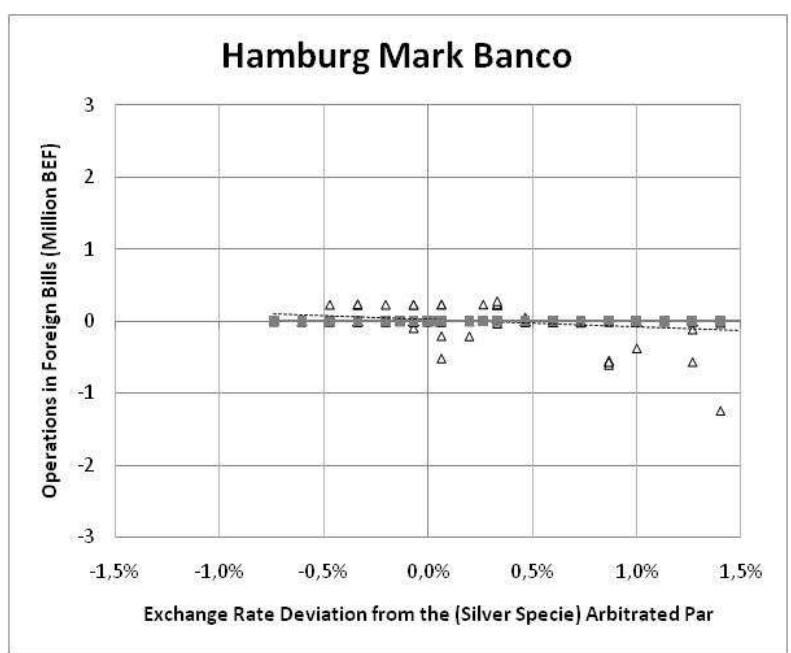

Figure 2.4: Operations on Hamburg marks Banco. 


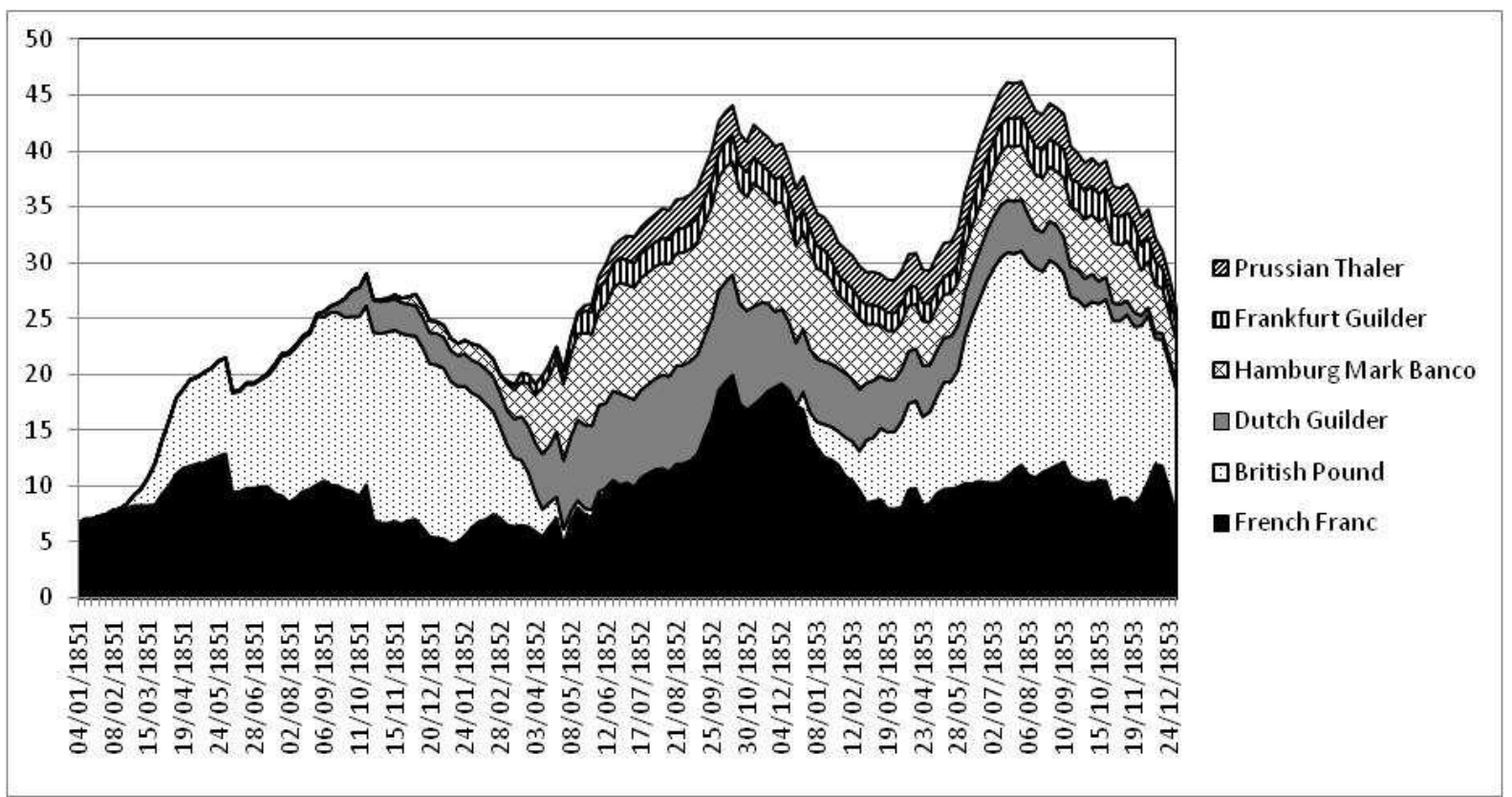

Figure 3: Composition of NBB foreign reserves (weekly, in million Belgian francs). Source: author. 


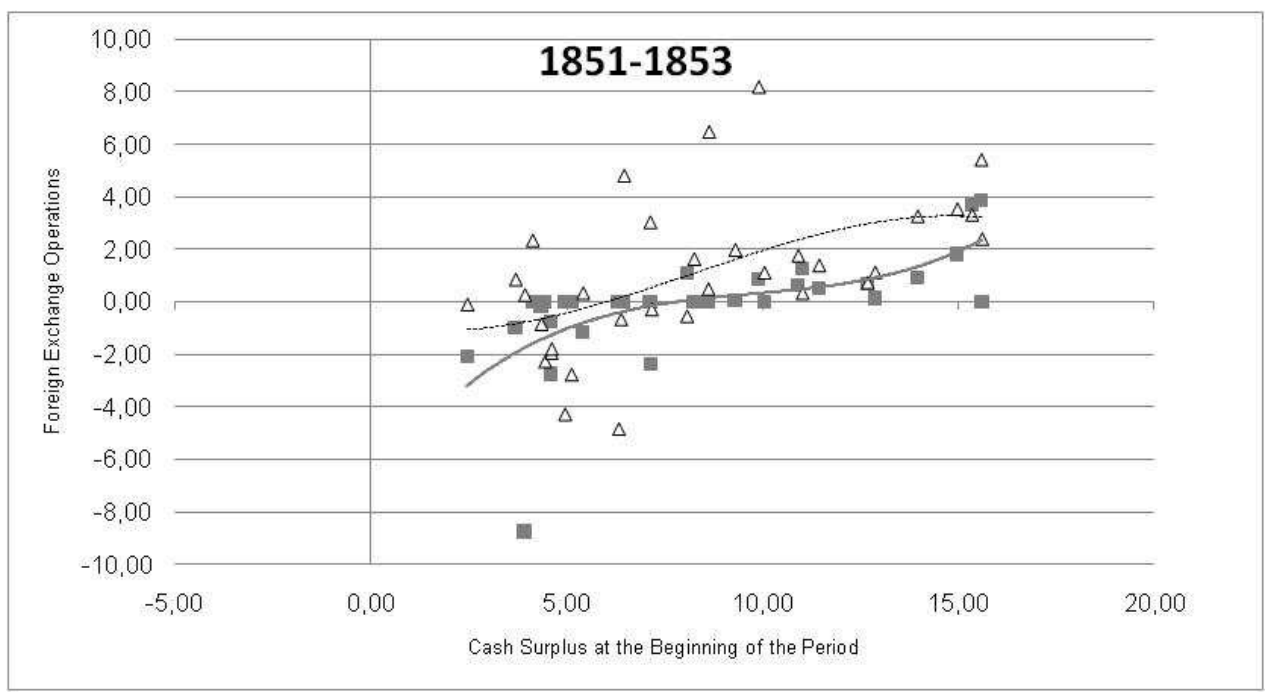

Figure 4: Monthly foreign exchange operations vis-à-vis the cash surplus at the beginning of the month (in million Belgian francs), 1851-1853. White triangles: non-sterilised operations; grey squares: sterilised operations. Source: author. 


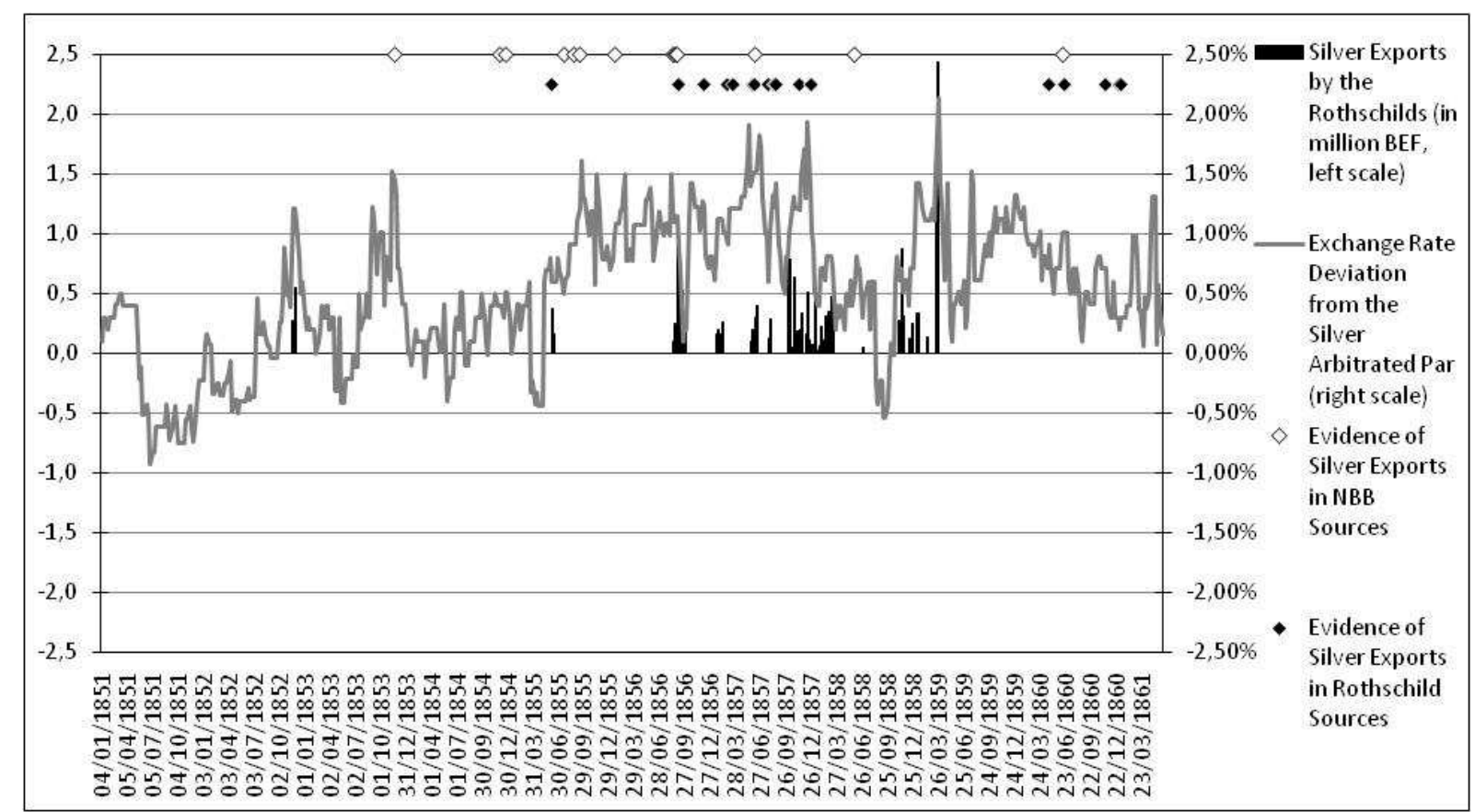

Figure 5: Exchange rate deviation from the arbitrated par and evidence of silver outflows from Belgium to Britain, 1851-1861. Gray line: Gross profitability of exporting silver species to Britain (right scale). Black bars: Silver shipments made by the Rothschild agent in Belgium to NM Rothschild \& Sons in London (in million francs, left scale). White lozenges: Qualitative evidence of silver exports by Belgian arbitrageurs in the NBB archives. Black lozenges: Qualitative evidence of silver exports by Belgian arbitrageurs in the correspondence of the Rothschild agent in Belgium. Sources: London interest rate: Ugolini (2010); Antwerp interest rate, see figure 1; exchange rate: Cours authentique de la Bourse de Bruxelles; Rothschild evidence: XI/38/212A-B (Richtenberger, 1851-1853) and XI/78/0A-2B (Lambert, 1853-1861); NBB evidence: PV CdA, 1851-1861. 


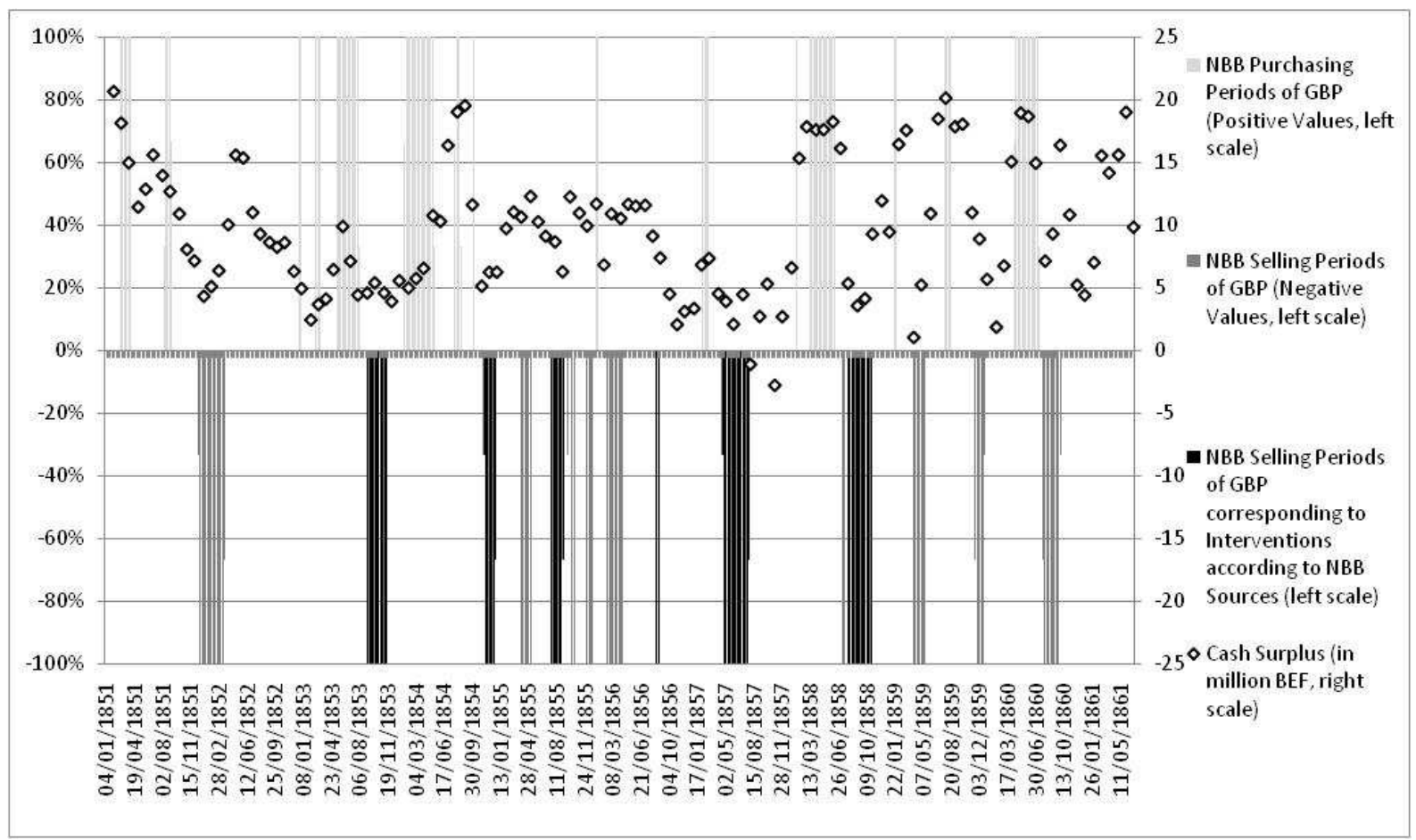

Figure 6: NBB interventions on the British pound exchange rate (defined as the percentage of the total weekly trading time during which the Bank has been purchasing $(+)$ or selling (-) claims denominated in British pounds, left scale) vis-à-vis the Bank's cash surplus (in million francs, right scale). Sources: author (PV CdA, RAG, 1851-1861). 


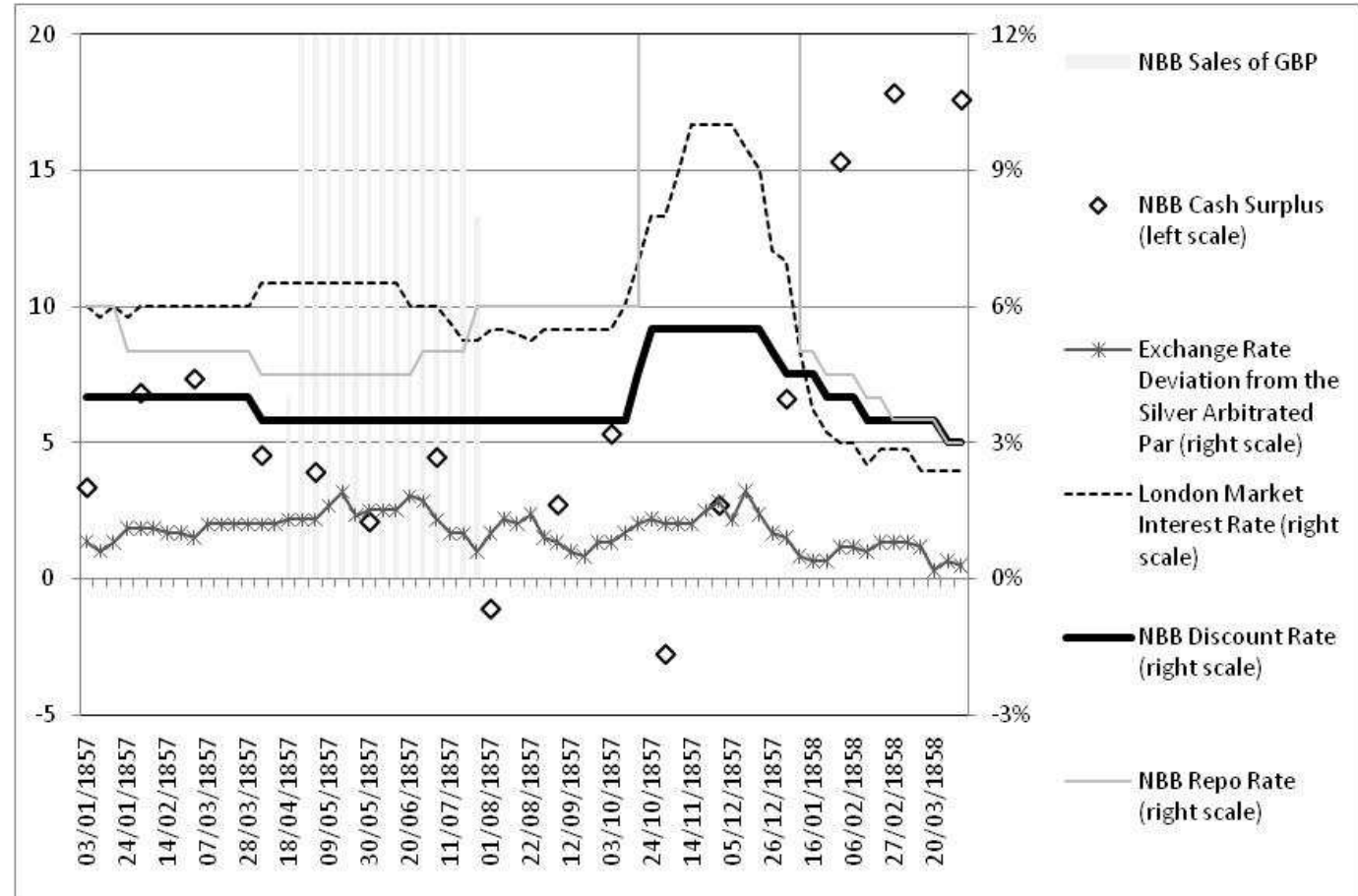

Figure 7: The NBB's reaction to the 1857 crisis. Sources: see figures 1, 5, and 6. 


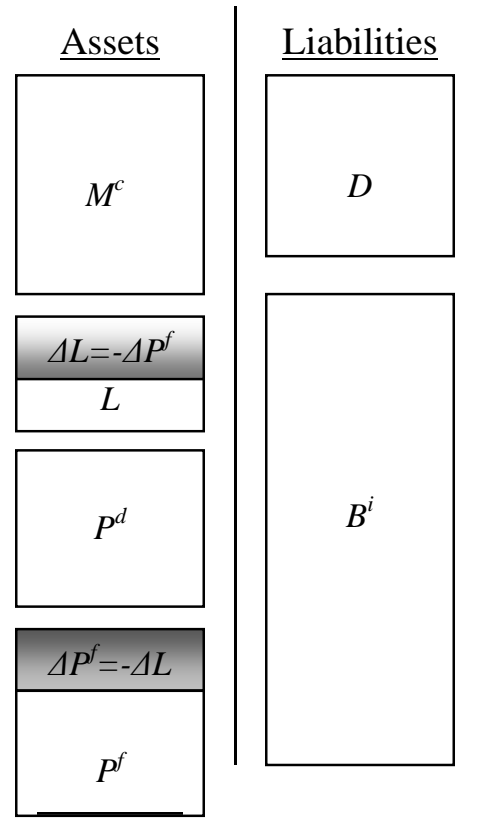

Diagram 1.1: Effect on the Bank's balance sheet of sterilised operations.

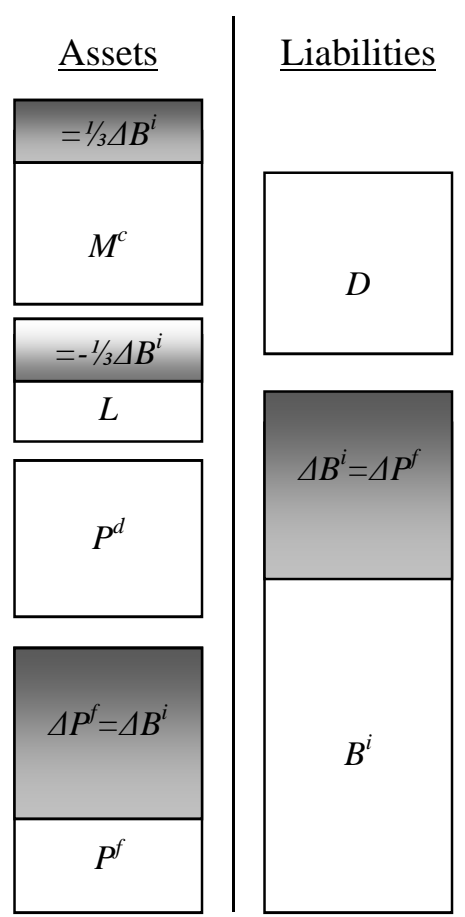

Diagram 1.2: Effect on the Bank's balance sheet of non-sterilised operations (right). 


\begin{tabular}{|l|r|}
\hline Differential & \multicolumn{1}{|c|}{$\begin{array}{c}\text { \% of } \\
\text { Weeks }\end{array}$} \\
\hline$-1,50 \%$ & $0,94 \%$ \\
$-1,00 \%$ & $2,44 \%$ \\
$-0,50 \%$ & $25,19 \%$ \\
Nil & $71,43 \%$ \\
\hline
\end{tabular}

Table 1: Differential between the domestic market rate and the NBB discount rate, 1851-1861. Sources: figure 1; PV CdA, 1851-1861. 


\begin{tabular}{|c|c|c|c|c|c|c|}
\hline \multicolumn{2}{|c|}{ Balance Sheet Components } & \multicolumn{2}{|c|}{ Minimum } & \multicolumn{2}{|c|}{ Maximum } & \multirow{2}{*}{$\frac{\text { Average }}{38,99 \%}$} \\
\hline \multirow{7}{*}{$\begin{array}{l}\tilde{\omega} \\
\hat{1} \\
\tilde{\psi}\end{array}$} & 1) Bullion Reserve $(M)$ & $30,67 \%$ & $31 / 01 / 1853$ & $79,96 \%$ & $31 / 01 / 1851$ & \\
\hline & 2) Belgian Treasury Securities & $0,34 \%$ & $31 / 01 / 1851$ & $14,56 \%$ & 29/02/1852 & $10,24 \%$ \\
\hline & 3) Advances on Treasury Securities & $1,26 \%$ & $31 / 01 / 1851$ & $9,94 \%$ & $28 / 02 / 1851$ & $6,59 \%$ \\
\hline & 4a) Foreign Portfolio $\left(P^{f}\right)$ & $3,78 \%$ & $31 / 01 / 1851$ & $31,58 \%$ & $31 / 07 / 1853$ & $22,06 \%$ \\
\hline & 4b) Domestic Commercial Portfolio $\left(P^{d}\right)$ & $10,42 \%$ & 28/02/1851 & $38,59 \%$ & $31 / 12 / 1853$ & $21,48 \%$ \\
\hline & 5) Real Estate & $0,49 \%$ & $31 / 12 / 1853$ & $0,92 \%$ & $31 / 05 / 1851$ & $0,62 \%$ \\
\hline & 6) Other & $0,00 \%$ & $31 / 12 / 1853$ & $0,16 \%$ & $31 / 07 / 1851$ & $0,02 \%$ \\
\hline \multirow{4}{*}{ 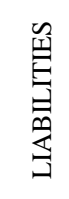 } & i) Capital and Reserves & $11,16 \%$ & $31 / 12 / 1853$ & $44,72 \%$ & $31 / 01 / 1851$ & $16,32 \%$ \\
\hline & ii) Banknotes in Circulation $\left(B^{i}\right)$ & $18,66 \%$ & $31 / 01 / 1851$ & $61,59 \%$ & $31 / 01 / 1853$ & $51,25 \%$ \\
\hline & iii) Deposits $(D)$ & $23,98 \%$ & $31 / 01 / 1853$ & $46,01 \%$ & $28 / 02 / 1851$ & $32,08 \%$ \\
\hline & iv) Other & $0,00 \%$ & $31 / 01 / 1851$ & $1,04 \%$ & $31 / 12 / 1852$ & $0,36 \%$ \\
\hline \multicolumn{2}{|c|}{ TOTAL BALANCE SHEET } & $33.542 .655,02$ & $31 / 01 / 1851$ & $137.348 .257,66$ & $31 / 12 / 1853$ & $103.864 .036,68$ \\
\hline
\end{tabular}

Table 2: Minimum, maximum, and average size of NBB balance sheet components, 1851-1853.

Sources: RAG, 1851-1853, except foreign portfolio (author). 


\begin{tabular}{|c|c|c|c|c|}
\hline & & & $\begin{array}{c}\text { (A) } \\
\text { Average } \\
\text { Opportunity } \\
\text { Cost } \\
\end{array}$ & $\begin{array}{c}\text { (B) } \\
\text { Average } \\
\text { Overvaluation }\end{array}$ \\
\hline \multirow{2}{*}{ French Franc } & Top 5* & Increases & $-0,07 \%$ & $0,00 \%$ \\
\hline & Top 5 & Decreases & $-0,04 \%$ & $0,00 \%$ \\
\hline \multirow{2}{*}{ British Pound } & Top 5 & Increases & $0,00 \%$ & $-0,17 \%$ \\
\hline & Top 5* & Decreases & $-0,04 \%$ & $0,52 \%$ \\
\hline \multirow{2}{*}{ Dutch Guilder } & Top 5 & Increases & $0,05 \%$ & $-0,21 \%$ \\
\hline & Top 5 & Decreases & $0,05 \%$ & $0,01 \%$ \\
\hline \multirow{2}{*}{ Hamburg Mark Banco } & Top 5 & Increases & $-0,10 \%$ & $-0,10 \%$ \\
\hline & Top 5 & Decreases & $-0,06 \%$ & $0,58 \%$ \\
\hline \multirow{2}{*}{ Frankfurt Guilder } & Top 3 & Increases & $0,21 \%$ & $-0,86 \%$ \\
\hline & Top 3 & Decreases & $-0,01 \%$ & $0,46 \%$ \\
\hline \multirow{2}{*}{ Prussian Thaler } & Top 3 & Increases & $-0,06 \%$ & $0,09 \%$ \\
\hline & Top 3 & Decreases & $0,19 \%$ & $0,57 \%$ \\
\hline
\end{tabular}

Table 3: Major reshufflings in the NBB foreign portfolio composition, vis-à-vis the average opportunity cost of the investment and the average overvaluation of the currency in that moment, 1851-1853. Major reshufflings are defined as the biggest weekly changes in the relative amount of the given currency held by the Bank with respect to the total size of foreign reserves. In the light of the different scale of operations, ten major reshufflings are identified for the most important currencies, and six for the least important ones. A big outlier (a special swap of British pounds for French francs implemented during the disturbances of December 1853) is not taken into account, as it falls in the category of 'extraordinary interventions' (see paragraph 4.3). Column A shows the average difference between the average quarterly interest rate yielded by a non-balanced basket of all six currencies and the quarterly market interest rate yielded by the given currency during the selected reshufflings. Column B shows the average overvaluation of the given currency during the selected reshufflings, defined as the exchange rate deviation from the arbitrated par. Sources: author. 